\title{
PENERAPAN DEMPSTER-SHAFER PADA SISTEM PAKAR DIAGNOSA PENYAKIT AKIBAT VIRUS VARICELLA-ZOSTER
}

\author{
Rohima Ritonga ${ }^{1}$ \\ ${ }^{1}$ Program Studi Teknik Informatika STMIK Budi Darma, Medan, Indonesia \\ Email: ${ }^{1}$ rohimaritonga0@gmail.com
}

\begin{abstract}
Abstrak
Varicella-zoster merupakan virus yang dapat menyebabkan varicella dan herpes zoster. Penyakit ini disebut sebagai cacar air karena gelembung atau bisul yang terbentuk pada kulit apabila pecah mengeluarkan air. Penyakit ini sangat mudah untuk menyebar kepada orang lain, terutama anak-anak yang belum pernah terkena varicella-zoster. Penyebaran virus ini terjadi melalui udara dan kontak langsung dengan penderita Sistem pakar adalah salah satu cabang dari AI yang membuat pengguna secara luas yang khusus untuk menyelesaikan masalah tingkat manusia yang pakar. Varicella zoster merupakan virus yang dapat menyebabkan varicella dan herpes zoster. Perangkat lunak yang dihasilkan mampu mendiagnosa dengan perhitungan nilai kepastian menggunakan metode DempsterShafer, dengan menggunakan bahasa pemograman visual basic yang dapat beraksi layaknya seorang pakar. Sistem ini dapat digunakan sebagai media konsultasi.
\end{abstract}

Kata kunci: Sistem Pakar, Varicella Zoster, Dempster Shafer

\section{Abstract}

Varicella-zoster is a virus that can cause varicella and shingles. This disease is referred to as chicken pox because bubbles or boils that form on the skin when it bursts out with water. This disease is very easy to spread to others, especially children who have never been exposed to varicella-zoster. The spread of this virus occurs through the air and direct contact with sufferers The expert system is one branch of AI that makes broad users specific to solving expert human-level problems. Varicella zoster is a virus that can cause varicella and shingles. The resulting software is able to diagnose certainty value calculations using the Dempster-Shafer method, using a visual basic programming language that can act like an expert. This system can be used as a consultation media.

Keywords: Expert System, Varicella Zoster, Dempster Shafer

\section{PENDAHULUAN}

Sistem pakar adalah salah satu cabang dari AI yang membuat pengguna secara luas yang khusus untuk menyelesaikan masalah tingkat manusia yang pakar. Seorang pakar adalah orang yang mempunyai keahlian dalam bidang tertentu yang mempunyai kemampuan khusus yang orang lain tidak mengetahui dan bisa melakukan dalam bidang yang dia miliki.

Varicella-zoster merupakan virus yang dapat menyebabkan varicella dan herpes zoster. Penyakit ini disebut sebagai cacar air karena gelembung atau bisul yang terbentuk pada kulit apabila pecah mengeluarkan air. Penyakit ini sangat mudah untuk menyebar kepada orang lain, terutama anak-anak yang belum pernah terkena varicella-zoster. Penyebaran virus ini terjadi melalui udara dan kontak langsung dengan penderita.

Virus Varicella-Zooster masuk dalam mukosa nafas atau orofaring, kemudian replikasi virus menyebar melalui pembuluh darah dan limfe( viremia pertama) kemudian berkembang biak di sel retikulo endhotellial setelah itu menyebar melalui pembuluh darah (viremia kedua) maka timbullah demam dan malaise. Permulaan bentuk lesi pada kulit mungkin infeksi dari kapiler endothelial pada lapisan papil dermis menyebar keselepitel pada epidermis, folikel kulit dan glandulasebacea dan terjadi pembengkakan. Lesi pertama ditandai dengan adanya makula yang berkembang cepat menjadi papula, vesikel dan akhirnya menjadi crusta. Jarang lesi yang menetap dalam bentuk macula dan papula saja. Vesikel ini akan berada pada lapisan sel dibawah kulit. Dan membentuk atap pada stratum korneum dan lusidum, sedangkan dasarnya adalah lapisan lebih dang

Degenarasi selakan diikuti dengan terbentuknya sel raksasa berinti banyak, dimana kebanyakan dari sel tersebut mengandung inclusion body intranuclear type A Penularan secara airborne droplet. Virus dapat menetap dan laten pada sel syaraf. Lalu dapat terjadi reaktivitas maka dapat terjadi herpes Zooster.

Penyakit ini umumnya terjadi pada orang dewasa dari pada anak-anak. Pada dewasa lebih sering diikuti nyeri pada kulit. Penyebab dari terinfeksi virus ini adalah belum pernah terkena cacar air, belum menerima vaksin cacar air, terutama ibu hamil, memiliki imunitas tubuh yang lemah, misalnya karena mengidap HIV, mengunakan obat-obatan steroid dan juga mempunyai kekebalan tubuh yang rendah. Perlu diketahui juga virus Varicellazoster bisa menyebabkan herpes zoster atau cacar ular. Penyakit ini ditandai dengan timbulnya bintil kulit berisi air pada salah satu sisi tubuh dan terasa nyeri.

Proses diagnose penyakit dapat dilakukan dengan menggunakan tekniksi sistem pakar. Perangkat lunak yang dihasilkan mampu mendiagnosa dengan perhitungan nilai kepastian menggunakan metode Dempster-Shafer, dengan menggunakan bahasa pemograman visual basic yang dapat beraksi layaknya seorang pakar. Sistem ini dapat digunakan sebagai media konsultasi.

Dalam penelitian sebelumnya yang dilakukan oleh Aprilia Sulistyohati dan Taufiq Hidayat dengan judul penelitian "Penerapan Metode Dempster-Shafer Pada Sistem Pakar Diaognosa Penyakit Akibat Virus varicella-zoster", dipublikasikan pada Jurnal Seminar NasionalAplikasiTeknologiInformasi2008 (SNATI 2008) ISSN: 1907-5022 
Yogyakarta, 21 Juni 2008 yang sudah dilakukan dan mendapatkan hasil dari penelitian tersebut, berupa kemungkinan penyakit Virus varicelle-zoster yang diderita berdasarkan gejala yang dirasakan oleh user. Sistem ini juga menampilkan besarnya kepercayaan gejala tersebut terhadap kemungkinan penyakit cacar yang diderita oleh user. Besarnya nilai kepercayaan tersebut merupakan hasil perhitungan dengan menggunakan metode Dempster-Shafer [1].

\section{TEORITIS}

\subsection{Sistem Pakar}

Sistem pakar merupakan salah satu bagian dari kecerdasaan buatan yang secara luas yaitu knowledge, terutama dalam penyelesaian masalah tingkat seorang pakar. Seorang pakar adalah orang yang memiliki keahlian khusus dalam bidang tertentu, yaitu pakar yang memiliki knowledge atau kemampuan khusus yang orang lain tidak mengetahui atau tidak mampu dalam bidang yang dimilikinya [1].

Menurut Giarratano dan Riley menyatakan bahwa sistem pakar adalah suatu sistem komputer yang bisa menyamai atau meniru kemampuan seorang pakar. Sistem ini bekerja untuk mengadopsi pengetahuan manusia ke komputer yang menggabungkan dasar pengetahuan dengan sistem inference untuk menggantikan fungsi seorang pakar dalam menyelesaikan suatu masalah [2]. Dari kedua pernyataan diatas, maka sistem pakar adalah kecerdasan buatan yang dapat meniru kemampuan seorang pakar secara luas dan bisa dapat menyelesaikan masalah sesuai dengan pikiran seorang pakar.

\subsection{Varicella Zoster}

Varicella adalah penyakit menular akut yang disebabkan oleh varicella zoster virus (VZV). Infeksi berulang dapat mengakibatkan terjadinya herpes zoster, dimana telah dikenal sejak lama. Infeksi varicella primer (cacar air) susah dibedakan dengan cacar sampai akhir abad ke-19. Pada tahun 1875, Steiner menunjukkan bahwa cacar air disebabkan oleh cairan vesikula yang berasal dari pasien dengan akut varicella. Observasi klinis mengenai hubungan antara varicella dan herpes zoster dibuat pada tahun 1888 oleh von Bokay, ketika anak-anak yang tidak terbukti memiliki kekebalan terhadap varicella setelah kontak dengan herpes zoster. VZV diisolasi dari kedua cairan vesikular yang berasal dari cacar air dan lesi zoster dalam kultur sel oleh Thomas Weller pada tahun 1954. Penelitian laboratorium virus itu selanjutnya menyebabkan pengembangan vaksin varicella hidup yang dilemahkan di Jepang pada 1970-an. Vaksin ini berlisensi untuk digunakan di Amerika Serikat pada Maret 1995. Vaksin pertama untuk mengurangi risiko herpes zoster ini dilisensikan pada Mei 2006.

VZV adalah virus DNA yang termasuk dalam famili virus herpes. Seperti virus herpes lainnya, VZV memiliki kapasitas untuk bertahan dalam tubuh setelah infeksi (pertama) primer sebagai infeksi laten. VZV tetap dalam ganglia saraf sensorik. Infeksi primer menyebabkan terjadinya varicella (cacar air), sementara herpes zoster (shingles) adalah akibat dari infeksi berulang. Virus ini diyakini memiliki waktu kelangsungan hidup singkat di lingkungan.

\subsection{Demspter Shafer}

Ada berbagai macam penalaran dengan model yang lengkap dan sangat konsisten, tetapi pada kenyataannya banyak permasalahan yang tidak dapat terselesaikan secara lengkap dan konsisten. Ketidak konsistenan yang tersebut adalah akibat adanya penambahan fakta baru. Penalaran yang seperti ini disebut dengan penalaran non monotonis. Untuk mengatasi ketidak konsistenan tersebut maka dapat menggunakan penalaran dengan teori Dempster-Shafer. Secara umum teori Dempster-Shafer ditulis dalam suatu interval :

[Belief,Plausibility].

Belief (Bel) adalah ukuran kekuatan evidence dalam mendukung suatu himpunan proposisi.Jika bernilai 0 maka mengindikasikan bahwa tidak ada evidence, dan jika bernilai 1 menunjukkan adanya kepastian. Plausibility (Pl) dinotasikan sebagai :

$\mathrm{Pl}(\mathrm{s})=1-\operatorname{Bel}(\ulcorner\mathrm{s})$

Plausibility juga bernilai 0 sampai 1. Jika yakin akan $\ulcorner$ s, maka dapat dikatakan bahwa $\operatorname{Bel}(\ulcorner\mathrm{s})=1$, dan $\operatorname{Pl}(\ulcorner\mathrm{s})=0$. Pada teori Dempster-Shafer dikenal adanya frame of discrement yang dinotasikan dengan $\theta$. Frame ini merupakan semesta pembicaraan dari sekumpulan hipotesis. Tujuannya adalah mengaitkan ukuran kepercayaan elemen-elemen $\theta$. Tidak semua evidence secara langsung mendukung tiap-tiap elemen.Untuk itu perlu adanya probabilitas fungsi densitas (m).Nilai m tidak hanya mendefinisikan elemen-elemen $\theta$ saja, namun juga semua subsetnya. Sehingga jika $\theta$ berisi $n$ elemen, maka subset $\theta$ adalah $\mathrm{n} 2$. Jumlah semua $\mathrm{m}$ dalam subset $\theta$ sama dengan 1 . Apabila tidak ada informasi apapun untuk memilih hipotesis, maka nilai : $\mathrm{m}\{\theta\}=1,0$.

Apabila diketahui $\mathrm{X}$ adalah subset dari $\theta$, dengan $\mathrm{m} 1$ sebagai fungsi densitasnya, dan $\mathrm{Y}$ jugamerupakan subset dari $\theta$ dengan $\mathrm{m} 2$ sebagai fungsi densitasnya, maka dapat dibentuk fungsi kombinasi $\mathrm{m} 1 \mathrm{dan} \mathrm{m} 2 \mathrm{sebagai} \mathrm{m} 3$ yaitu :

$$
m 3(Z)=\frac{\sum_{\mathrm{x} \cap \mathrm{y}=\mathrm{z}} \mathrm{m} 1(\mathrm{X}) \cdot \mathrm{m} 2(\mathrm{Y})}{1-\sum_{\mathrm{x} \cap \mathrm{y}=\emptyset} \mathrm{m} 1(\mathrm{X}) \cdot \mathrm{m} 2(\mathrm{Y})}
$$

Keterangan :

$\mathrm{m} 3(\mathrm{Z})=$ mass function dari evidence $(\mathrm{Z})$

b. $\mathrm{m} 1(\mathrm{X})=$ mass function dari evidence $(\mathrm{X})$ 
$\mathrm{m} 2(\mathrm{Y})=$ mass function dari evidence $(\mathrm{Y})$

$\mathrm{Zm} 1(\mathrm{X}) \cdot \mathrm{m} 2(\mathrm{Y})=$ ada hasil irisan dari $\mathrm{m} 1$ dan $\mathrm{m} 2$

$\theta \mathrm{Zm} 1(\mathrm{X}) \cdot \mathrm{m} 2(\mathrm{Y})=$ tidak ada hasil irisan (irisan kosong $(\theta)$ )

\section{ANALISA DAN PEMBAHASAN}

Tahapan analisis terhadap suatu sistem dilakukan sebelum tahapan perancangan dilakukan. Tujuan diterapkannya analisis terhadap suatu sistem adalah untuk mengetahui alasan mengapa sistem tersebut diperlukan, sehingga fungsi yang terdapat di dalam sistem tersebut bekerja secara optimal. Salah satu unsur pokok yang harus dipertimbangkan dalam tahapan analisis sistem ini yaitu masalah perangkat lunak, karena perangkat lunak yang digunakan haruslah sesuai dengan masalah yang akan diselesaikan.

Dalam tahapan ini dilakukan pencarian dan pengumpulan data serta pengetahuan yang diperoleh dari seorang pakar, sehingga pada akhirnya analisa yang didapat harus berupa sistem dengan baik dan jelas. Sistem yang dibangun untuk menentukan bahwa penyakit akibat virus varicella zoster yaitu dengan cara melakukan konsultasi dengan seorang pakar yang memang spesialis kulit. Maka dari itu, penulis mencoba membuat sistem pakar yang dapat membantu seorang pakar untuk mengetahui gejala penyakit akibat virus varicella zoster. Adapun gejala-gejala penyakit akibat virus varicella yang dibahas adalah sebagai berikut :

Tabel 1. Gejala Penyakit Akibat Virus Varicella Zoster

\begin{tabular}{ccl}
\hline No. & Kode Gejala & \\
\hline 1. & G1 & Kulit Terasa Perih \\
2. & G2 & Badan terasa gatal-gatal \\
3. & G3 & Kulit terasa terbakar \\
4. & G4 & Demam \\
5. & G5 & Nyeri Tertusuk-tusuk Pada Kulit \\
6. & G6 & Luka Merah \\
7. & G7 & Lepuhan Berisi Cairan \\
8. & G8 & Ruam kemerahan \\
9. & G9 & Gatal yang dapat terasa parah \\
10. & G10 & Kering \\
11. & G11 & Pembengkakan \\
12. & G12 & Kulit kering atau bersisik \\
13. & G13 & Merasa Tidak Sehat \\
14. & G14 & Menebal \\
15. & G15 & Kesulitan bernapas atau menelan \\
16. & G16 & Bengkak mata atau wajah \\
\hline
\end{tabular}

Mesin inferensi merupakan bagian dari sistem pakar yang melakukan penalaran mengenai informasi yang ada dalam basis pengetahuan untuk menformulasikan kesimpulan. Secara umum terdapat data pendekatan yaitu pelacakan kedepan (Forward Chaining dan pelacakan kebelakang (Backward Chaining).

Forward Chaining adalah pendekatan yang dimotori oleh data (data driver). Pendekatan pelacakan ini dimulai dari tujuan dan selanjutnya mencoba menggambarkan kesimpulan atau solusi yang diharapkan. Sedangkan Backward Chaining adalah pendekatan yang dimotori tujuan (goal driver). Pada pendekatan pelacakan dimulai dari tujuan dan selanjutnya dicari aturan-aturan yang memiliki tujuan tersebut dan dicari kesimpulan atau pembuktiannya.

Pada sistem pakar untuk mendiagnosa penyakit menggunakan metode Dempster Shafer dengan menentukan dahulu gejala-gejala yang dialami, lalu melakukan analisis setelah itu melakukan proses perhitungan dengan metode Dempster Shafer dan akan diketahui jenis penyakit yang diderita oleh seseorang.

Tabel 2. Nilai Kepastian Dempster Shafer

\begin{tabular}{cccc}
\hline No. & Rating Kepastian & Nilai Kepastian & Keterangan \\
\hline 1. & $90 \%-100 \%$ & 1 & Sangat Yakin \\
2. & $80 \%-89 \%$ & 0,75 & Yakin \\
3. & $50 \%-79 \%$ & 0,5 & Cukup Yakin \\
4. & $<50 \%$ & 0,25 & Kurang Yakin \\
\hline
\end{tabular}

Tabel 3. Nilai Densitas Penyakit

\begin{tabular}{clc}
\hline \multicolumn{1}{c}{ Gejala } & Nilai Densitas \\
\hline No. & \multicolumn{1}{c}{ Kulit Terasa Perih } & 0,8 \\
2. & Badan terasa gatal-gatal & 0,8 \\
3. & Kulit terasa terbakar & 0,7 \\
\hline
\end{tabular}




\begin{tabular}{clc} 
4. & Demam & 0,5 \\
5. & Nyeri Tertusuk-tusuk Pada Kulit & 0,75 \\
6. & Luka Merah & 0,75 \\
7. & Lepuhan Berisi Cairan & 0,7 \\
8. & Ruam kemerahan & 0,5 \\
9. & Gatal yang dapat terasa parah & 0,7 \\
10. & Kering & 0,6 \\
11. & Pembengkakan & 0,5 \\
12. & Kulit kering atau bersisik & 0,4 \\
13. & Merasa Tidak Sehat & 0,4 \\
14. & Menebal & 0,5 \\
15. & Kesulitan bernapas atau menelan & 0,6 \\
16. & Bengkak mata atau wajah & 0,7 \\
\hline
\end{tabular}

\subsection{Penerapan Metode Dempster Shafer}

Setelah menentukan basis pengetahuan maka tahap selanjutnya menggunakan mesin inferensi dengan melakukan proses perhitungan dengan metode Dempster Shafer. Untuk melakukan perhitungan dalam memastikan penyakit akibat virus varicella zoster yang diderita perlu dilakukan perhitungan dengan metode Dempster Shafer sebagai berikut :

Tabel 4. Contoh kasus, user memilih gejala :

\begin{tabular}{cclc}
\hline No. & Kode & \multicolumn{1}{c}{ Gejala } & Bobot \\
\hline 1. & G1 & Kulit Terasa Perih & 0,8 \\
2. & G2 & Badan terasa gatal-gatal & 0,8 \\
3. & G7 & Lepuhan berisi cairan & 0,7 \\
\hline
\end{tabular}

G1, G2, G9 merupakan gejala dari penyakit Herpes Simpleks Diseminata. Maka untuk menghitung nilai Demspter Shafer penyakit akibat virus varicella zoster pada pasien yang dipilih dengan menggunakan nilai belief yang telah ditentukan pada setiap gejala.

$\operatorname{P} 1(\Theta)=1-$ BEL

Dimana nilai BEL (belief) merupakan nilai bobot yang di input oleh pakar, maka untuk mencari dari kedua gejala diatas, terlebih dahulu dicari nilai $\Theta$, seperti yang dibawah ini :

\begin{tabular}{|c|c|}
\hline Gejala 1 & : Kulit Terasa Perih (G \\
\hline Maka & $: \mathrm{G} 1(\mathrm{BEL})=0,8$ \\
\hline & $\begin{aligned} \mathrm{G} 1(\Theta) & =1-0,8 \\
& =0,2\end{aligned}$ \\
\hline
\end{tabular}

Gejala $2 \quad$ : Badan terasa gatal-gatal $(\mathrm{G} 2)$

Maka $\quad: \mathrm{G} 1(\mathrm{BEL})=0,8$

$\mathrm{G} 1(\Theta)=1-0,8$

$=0,2$

Gejala 3 : Lepuhan berisi cairan (G7)

Maka $: \mathrm{G} 1(\mathrm{BEL})=0,7$

$$
\begin{aligned}
\mathrm{Gl}(\Theta) & =1-0,7 \\
& =0,3
\end{aligned}
$$

Maka untuk mencari nilai dari GPn, digunakan rumus :

$m 3(Z)=\frac{\sum_{\mathrm{x} \cap \mathrm{y}=\mathrm{z}} \mathrm{m} 1(\mathrm{X}) \cdot \mathrm{m} 2(\mathrm{Y})}{1-\sum_{\mathrm{x} \cap \mathrm{y}=\emptyset} \mathrm{m} 1(\mathrm{X}) \cdot \mathrm{m} 2(\mathrm{Y})}$

Keterangan :

a. $\mathrm{m} 3(\mathrm{Z})=$ mass function dari evidence $(\mathrm{Z})$

b. $\mathrm{m} 1(\mathrm{X})=$ mass function dari evidence $(\mathrm{X})$

a. $\mathrm{m} 2(\mathrm{Y})=$ mass function dari evidence $(\mathrm{Y})$

b. $\mathrm{Zm} 1(\mathrm{X}) \cdot \mathrm{m} 2(\mathrm{Y})=$ ada hasil irisan dari $\mathrm{m} 1$ dan $\mathrm{m} 2$

c. $\mathrm{OZm1}(\mathrm{X}) \cdot \mathrm{m} 2(\mathrm{Y})=$ tidak ada hasil irisan (irisan kosong $(\Theta)$

Maka nilai GPn dari gejala diatas adalah :

$$
\begin{aligned}
\mathrm{GPn} & =\frac{0,8 * 0,8 * 0,7}{1-(0,2 * 0,2 * 0,3)} \\
& =0,448 / 0,988 \\
& =0,45=0,5
\end{aligned}
$$

Maka nilai densitas ketiga gejala tersebut adalah 0,5. Dengan nilai densitas 0,5 maka pasien memiliki evidence yang cukup yakin terdiagnosa.

\section{KESIMPULAN}


Dari hasil penulisan dan analisa dari bab-bab sebelumnya, maka dapat diambil kesimpulan-kesimpulan, dimana kesimpulan-kesimpulan tersebut kiranya dapat berguna bagi para pembaca, sehingga penulisan skripsi ini dapat lebih bermanfaat. Adapun kesimpulan-kesimpulan tersebut adalah sebagai berikut :

1. Proses diagnosa terhadap penyakit harus dilakukan kepada seorang ahlinya atau spesialis yang mengerti atau paham terhadap penyakit tersebut. Didalam diagnosa penyakit akibat virus varicella zoster diperlukan sebuah sistem atau aplikasi yang dapat mempermudah para pasien atau masyarakat yang akan melakukan diagnosa.

2. Cara menerapkan Metode Dempster Shafer dalam melakukan diagnosis dapat memerlukan data training yang berhubungan dengan kasus yang diteliti sehingga akan lebih mudah untuk mendapatkan hasilnya.

3. Aplikasi sistem pakar untuk mendiagnosa penyakit akibat virus varicella zoster telah selesai dirancang menggunakan Visual basic.Net 2008 dan dapat digunakan dengan baik.

\section{REFERENCES}

[1] S. Nurhena, N. A. Hasibuan and K. Ulfa, "Sistem Pakar Mendiagnosa Virus Mayora Dengan Metode Variable Centered Intelligent Rule System (Vcirs)," Konferensi Nasional Teknologi Informasi dan Komputer (KOMIK), vol. 2, no. 1, pp. 109115,2018

[2] D. Ayuningsih and N. A. Hasibuan, "Sistem Pakar Mendiagnosa Kerusakan Pada Mesin Penggilingan Padi Menggunakan Metode Naive Bayes," Jurnal Riset Komputer (JURIKOM), vol. 5, no. 4, pp. 371-376, 2018.

[3] A. Desiani and M. Arhami, Konsep Kecerdasan Buatan, Yogyakarta: CV. Andi Offset, 2016.

[4] M. Arhami, Konsep Dasar Sistem Pakar, Yogyakarta: CV. Andi Offset, 2005.

[5] D. P. Utomo and S. D. Nasution, "SISTEM PAKAR MENDETEKSI KERUSAKAN TONER DENGAN MENGGUNAKAN METODE CASE BASED-REASONING," Jurnal Riset Komputer (JURIKOM), vol. 3, no. 5, pp. 430-434, 2016.

[6] "Kamus Besar Bahasa Indonesia," [Online]. Available: https://kbbi.web.id/diagnosis. [Accessed 18 Mei 2019].

[7] "Wikipedia Ensiklopedia Bebas," [Online]. Available: https:id.m.wikipedia.org/wikipedia. [Accessed 18 Mei 2019].

[8] A. Nugroho, Analisis dan Perancangan Sistem Informasi dengan Metodologi Berorientasi Objek Edisi Revisi, Bandung: Informatika, 2005.

[9] R. A.S and M. Shalahuddin, Rekayasa Perangkat Lunak Terstruktur dan Berorientasi Objek Edisi Revisi, Bandung: Informatika, 2011.

[10] J. HM, Analisa dan Desain Sistem Informasi, Yogyakarta: Andi Publisher, 2005.

[11] Hendrayudi, VB 2008 untuk Berbagai Keperluan Pemrograman, Jakarta: PT. Elex Media Komputindo, 2009.

[12] P. A. d. Solusi (PAS), Membuat Aplikasi Client Server dengan Visual Basic 2008, Yogyakarta: Penerbit : Andi, 2010. 